\title{
Shell Seal Breakdown in Almond is Associated with the Site of Secondary Ovule Abortion
}

\author{
T.M. Gradziel ${ }^{1}$ \\ Department of Pomology, University of California, Davis, CA, 95616 \\ P. Martínez-Gómez \\ Departamento de Mejora y Patología Vegetal, CEBAS-CSIC, PO Box 4158, Murcia, Spain
}

AdDitional INDEX wORDs. Prunus dulcis, endocarp, split pits, lignin, suture, ripening

\begin{abstract}
California almonds [Prunus dulcis, syn. P. amygdalus, P. communis] possess a moderately lignified 'paper' shell rather than the stony, peach-pit type shells common to European and Asian cultivars. At nut maturity, more than $70 \%$ of shells of the principal California cultivar Nonpareil can be split. Use of a mechanical shaker to harvest nuts increased the proportion of nuts with split shells by $40 \%$ when compared to hand harvest. All shell splitting occurred at the ventral suture with $\sim 80 \%$ of the splits occurring at the site of the degenerating funiculus leading to the aborted or secondary ovule. Remaining splits occurred near the site of the funiculus feeding the viable ovule, and only rarely at the suture line. Abortion of one of the two ovules in the almond ovary is often initiated at or shortly after bloom, and so the final site of shell splitting appears to be predetermined early in fruit development. Measurements of the strength of the inner endocarp wall at 50 days after flowering showed distinct weaknesses in the areas of the developing funiculi. Similarly, damage to the developing kernel at 60 days after flowering by the leaffooted bug (Leptoglossus clypealis Heiderman) occurred along the ventral suture, with $80 \%$ of the damage located at the point of attachment of the secondary funiculus.
\end{abstract}

Almond (Prunus dulcis, syn. P. amygdalus, P. communis) is a major nut crop with world commercial production estimated at over 490,000 t in 1999 (Almond Board of California, 2000). Production is almost entirely in Mediterranean type climates, often under low-input and dryland cropping systems. Most European and Asian cultivars possess a thick shell derived from the lignification of the fruit endocarp, which protects the kernel from insect damage and disease infection (Crane and Summers, 1971; Kester et al., 1991; Soderstrom, 1977). The endocarp often accounts for $>60 \%$ of total nut dry weight resulting in a low kernel-to-nut mass ratio (crack-out), greater mechanical difficulty in shelling kernels, and greater damage to kernel meats during shelling. The utilization of high-yielding cultivars combined with high-input orchard management practices has made California a leading producer of almonds with production of 377,000 $t$ in 1999 (Almond Board of California, 2000).

Shells of high yielding California cultivars are thin and only moderately lignified with crack-out ratios from $45 \%$ to $75 \%$ (Kester et al., 1991). Lower shell mass is associated with greater damage during nut development from the hemipterous insects lygus bug (Lygus hesperus Knight) and leaffooted bugs (Leptoglossus clypealis), and at nut maturity from the more destructive lepidopterous insects navel orangeworm (Amyelois transitella Walker) and to a lesser extent peach twig borer (Anarsia lineatella Zeller). Insect damage to the mature seedcoat tissue, which normally acts as a barrier to fungal infection, results in a greater incidence of kernel infections by aflatoxin-causing Aspergillus Speare sp. (Fuller et al., 1977; Phillips et al., 1976; Schade et al., 1975; Schatzki, 1996). The almond fruit hull, a leathery and tannic mesocarp derived tissue, protects the immature kernel from insects and disease. At nut maturity, however, the hull dries and splits, leaving the shell as the

Received for publication 4 Apr. 2001. Accepted for publication 23 Aug. 2001. The authors gratefully acknowledge support of the Spanish Ministry of Education and Culture during the study leave of Pedro Martínez-Gómez in the U.S. The cost of publishing this paper was defrayed in part by the payment of page charges. Under postal regulations, this paper therefore must be hereby marked advertisement solely to indicate this fact.

${ }^{1}$ Corresponding author. remaining barrier to insect attack (Weiss, 1988). Over $90 \%$ of insect damage to California almonds occurs following hull split, through cracks in the endocarp (Crane and Summers, 1971; Curtis and Barnes, 1976; Freeman et al., 1998; IPM Manual Group, 1985). The integrity of the mature shell varies with genotype, with the proportion of intact nuts ranging from $90 \%$ and higher in semi-hard-shelled cultivars such as 'Mission', to as low as $20 \%$ in soft paper-shelled cultivars such as 'Merced'. 'Nonpareil', the major California almond cultivar which accounts for $\approx 44 \%$ of total production (Almond Board of California, 2000), has a thin paper shell with a crackout ratio of $\approx 65 \%$ and average proportion of well-sealed nuts of $\approx 60 \%$.

Cultural practices, including crop load, scheduling of fertilizer and irrigation application, and rootstock selection, influence the final extent of endocarp fracturing in susceptible cultivars of almond (Hawker and Buttrose, 1980; IPM Manual Group, 1985) and peach [(Prunus persica (L.) Batsch (subgenus Amygdalus)] (Miki, 1932; Ryugo, 1962). Endocarp fracturing in peach, commonly known as split pits, is believed to occur when rapid mesocarp expansion leads to separation or fracturing of the more rigid endocarp at the ventral suture line, as this is one of the last areas to lignify during fruit development (Ryugo, 1962). Cultural practices associated with increased levels of split pits in peach are also associated with accelerated mesocarp expansion. Almond fruit, while structurally similar to peach, lack a rapid mesocarp expansion after endocarp lignification. The mature almond endocarp, unlike the more uniform and highly lignified peach endocarp, consists of a partially lignified central layer containing the vascular bundles sandwiched between a more highly lignified inner layer and an outer layer with moderate lignification. In addition, while almond shell fractures occur at the suture, they are usually adjacent and parallel to the suture line.

The continuing loss of chemical insecticides traditionally used to control almond pests has made natural barriers to insects and disease, such as well-sealed shells, attractive alternatives. The objective of this study was to characterize shell seal breakdown in 'Nonpareil' almond and assess opportunities for its cultural and genetic manipulation. 


\section{Materials and Methods}

FrequenCy AND LOCATION OF SHELL FRACTURES. Samples were collected from 8-year-old 'Nonpareil' almond trees growing under standard commercial conditions in regional cultivar trials at Chico, Calif. (northern Sacramento Valley), Winters, Calif. (southern Sacramento Valley), and Manteca, Calif. (northern San Joaquin Valley). Five hundred nuts (including endocarp, seed and occasionally attached hulls) were randomly collected $\approx 185 \mathrm{~d}$ after flowering (DAF) from the orchard floor at the Chico plot following mechanical-shaker harvesting in 1999. In 2000, samples were collected randomly both before and following mechanical harvesting of trees at the Winters (180 DAF) and Manteca (175 DAF) plots. Nuts were examined visually, and when necessary, under a stereomicroscope, and scored for the presence and location of shell fractures. Fractures along the ventral vascular bundles located adjacent to and parallel with the suture, were characterized further by the condition of the adjacent ovule. The almond fruit has a single ovary containing two functional ovules with funicular attachments on either side of the suture line. One ovule, designated the secondary ovule, usually aborts in 'Nonpareil' and other California almonds.

STRUCTURAL INTEGRITY OF DEVELOPING ENDOCARP. Samples of eight fruit each were collected at $\approx 50 \mathrm{DAF}$ from four separate trees at the Manteca regional almond cultivar trial. Sample fruit were cut longitudinally parallel to the suture line, and the strength of the inner endocarp tissue at $10,45,90,135,170,190,225,270,315$, and $350^{\circ}$ relative to the peduncle (Fig. 1) was measured using a mechanical force gauge (model L-10-M; U.C. Hunter Spring) (Ametek, Hatfield,Pa.) as described by Reid (1992) with a 1-mm flat probe. Measurement was on the tangential plane offset $10^{\circ}$ from the suture line so as to pass through the secondary funiculus (Fig. 1). Endocarp strength was measured similarly in a crosssectional plane at the points of funiculi attachment about midway between the fruit midsection and the distal, stylar fruit tip, (Fig. 1). Measurements were taken at 0, 10, $45,90,135,180,225,270,315$, and $350^{\circ}$ relative to the suture line. For consistency, the site of funiculus attachment to the secondary (aborted) ovule was chosen as the $10^{\circ}$ measurement position (Fig. 1), with measurements continuing in a circular pattern culminating in the position of primary (nonaborted) ovule attachment $\left(350^{\circ}\right)$ with the suture line at $0^{\circ}$. Similar fruit crosssections were examined from 60 to 150 DAF following placement of the cut fruit surfaces in $10 \%$ toluidine blue stain for 10 minutes to stain lignin-containing cells in the developing fruit. Color equalization software (Canvas 7; Deneba Systems, Inc., Miami, Fla.) was used to minimize the saturation of background fruit colors and convert the intensity of the blue-violet staining of lignified tissue to grey scales of comparable intensities.

Frequency AND LOCATION OF KERNEL DAMAGE BY LEAFFOOTED BUG. One hundred

\section{Longitudinal section}

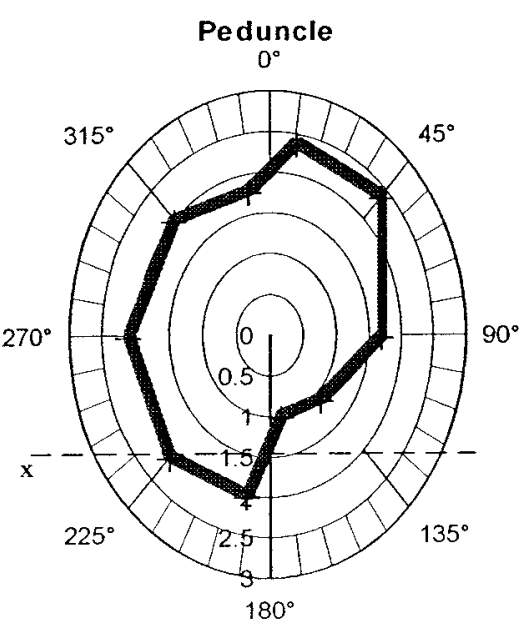

\section{Puncture Force (kg)}
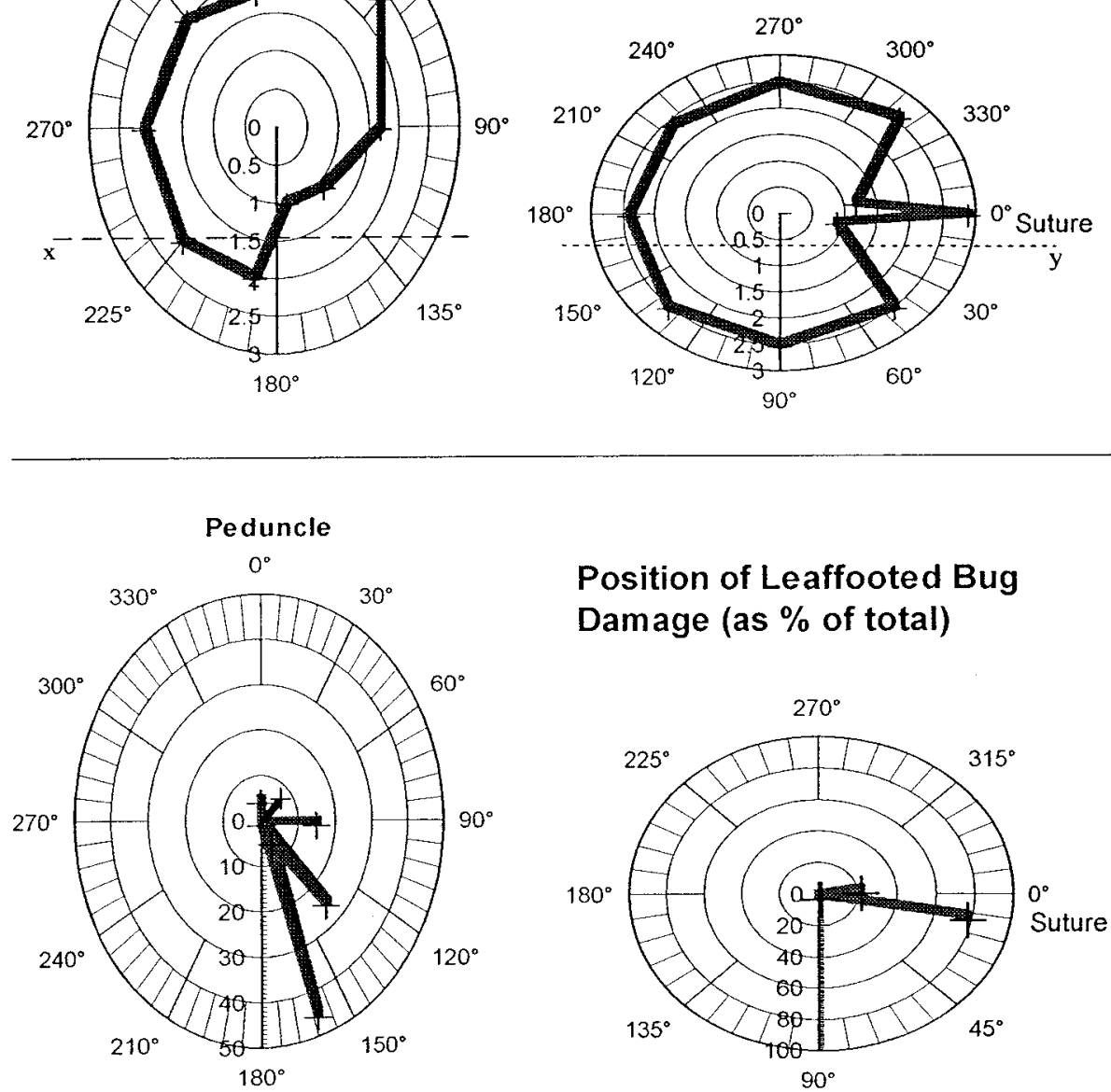

\section{Position of Leaffooted Bug Damage (as \% of total)}

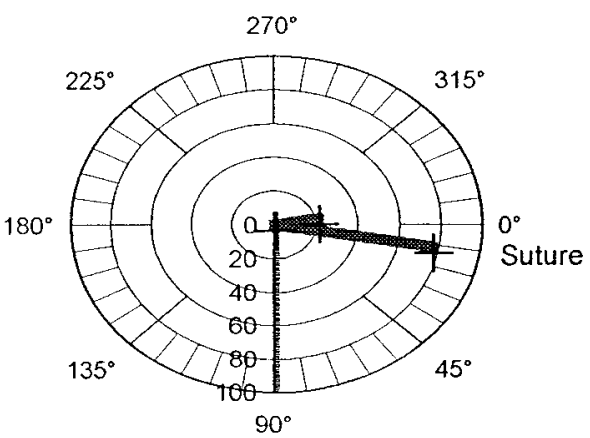




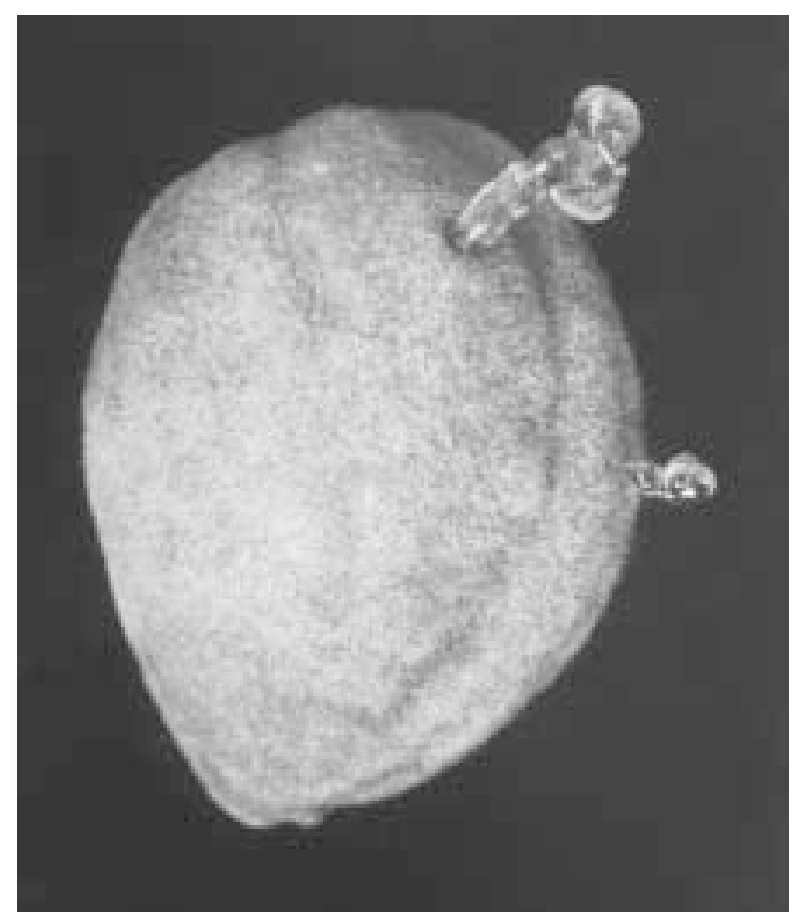

Fig. 2. Almond fruit wound with extruding gum resulting from leaffooted bug feeding at the ventral suture at $\approx 45^{\circ}$ and $90^{\circ}$ relative to the peduncle.

harvested almonds sampled in 1999 (Table 1). Fractures occurred as a splitting along the ventral side of the shell near the suture. Splitting at the suture line occurred in only one of the 500 nuts sampled. Shell splits in the remaining nuts occurred adjacent and parallel to the suture at the base of the thickly lignified shell wing commonly found in 'Nonpareil' and other California cultivars (Fig. 3). Splits ranged in width from $<1 \mathrm{~mm}$, to up to $1 \mathrm{~cm}$, and up to several centimeters in length. Most shell splitting occurred along the distal portion of the suture near the funiculus (Fig. 3). The outer layer of the 'Nonpareil' shell was soft and papery, and easily flaked away from the only partially lignified middle layer containing the vascular bundles. The inner, more highly lignified shell layer was the most resistant to splitting. There was no difference in the occurrence of embryo abortion between the two funiculi positions within the fruit (data not presented). The specific site of shell split initiations, however, could be identified in 294 of the 361 fractured nuts sampled in 1999 and the majority of such fractures (78.2\%) were located along the secondary funiculus leading to the aborted or secondary ovule (Table 1). This frequency was significantly different from an assumption of equal probabilities for the two funiculi. Similar observations were made for samples collected in 2000 from Manteca and
Winters, Calif. (Table 1). The proportion of mechanically harvested nuts showing split shells was $51 \%$ for both locations. When the nuts were hand-harvested from the trees just prior to mechanical harvesting, a $40 \%$ reduction in the proportion of damaged shells was observed. As in 1999, splits at the suture line were rare ( 3 in 337 fruit), with the majority ( $74 \%$ to $89 \%$ ) of remaining splits occurring at the secondary (aborted) funiculus (Table 1, Fig. 3). Ratios were again significantly different $(P<$ 0.005 ) from an assumption of equal probabilities of splitting at the two funiculi.

STRUCTURAL INTEGRITY OF DEVELOPING ENDOCARP. Immature nuts sampled at 50 DAF from the Manteca orchard showed a relatively firm inner-endocarp wall, though with significantly reduced strength near the peduncle $\left(350^{\circ}\right)$ and more extensively, at the distal, ventral suture (from 90 to $180^{\circ}$ in the longitudinal sections in Fig. 1, and Tables 2 and 3). Measurements in the crosssectional plane also showed uniform firmness for the innerendocarp wall but with significantly reduced strength at the two funiculi $\left(10\right.$ and $\left.350^{\circ}\right)$ and a significantly greater strength at the suture line $\left(0^{\circ}\right)$ (Tables 2 and 3$)$. Endocarp wall strength at the degenerating, secondary funiculus was slightly though significantly less than at the functional primary funiculus. The position $\mathrm{x}$ tree interaction for cross-section data (Table 3) was also significant, presumably due to small differences in nut maturity among trees. Similar patterns of endocarp strength were observed for fruit harvested at 54 DAF from Winters, Calif. (data not presented). Toluidine blue staining of fruit cross sections at this stage of development showed lignification occurring throughout the endocarp but being more intense at the inner endocarp and at the ventral suture region including the vascular strands of the funiculi and ventral vascular bundles. By 130 DAF, lignin was well-distributed within the 'Nonpareil' endocarp though with apparent discontinuities in lignin density at the funiculi and at the suture line (Fig. 4).

FREQUENCY AND LOCATION OF KERNEL DAMAGE BY LEAFFOOTED BUG. Leaffooted bug damage to immature fruit at 60 DAF occurred as a physical wounding of the fruit surface followed by a distinct gum exudation (Fig. 2). Feeding damage was observed on all fruit surfaces but was more common on the distal portions of the fruit, particularly near the ventral suture. Leaffooted bug damage extending to the developing kernel was found in only 21 of the 100 damaged fruit dissected (Table 4). While feeding damage at the hull surface was distributed widely, feeding damage to the developing kernel was limited to the ventral suture area and occurred almost entirely at the secondary funiculus (Table 4 and Fig. 1). At this stage of nut development, the inner endocarp had a semi-hard eggshell-like appearance with moderate levels of lignification as observed as a dense blue-violet staining following 10 min immersion in toluidine blue. Damaged kernels usually continued to develop though often with tissue shriveling at the

Table 1. Proportion of almond nuts showing split shells, and location of splits for affected shells. Percentages are in parentheses.

\begin{tabular}{|c|c|c|c|c|c|c|c|c|c|c|c|c|c|}
\hline \multirow{3}{*}{$\frac{\text { Year }}{1999}$} & \multirow{3}{*}{$\begin{array}{c}\text { Source } \\
\text { Chico }\end{array}$} & \multirow{3}{*}{$\frac{\text { Harvest }}{\text { Mechanical }}$} & \multirow{3}{*}{$\begin{array}{c}\begin{array}{c}\text { Sample } \\
\text { size }\end{array} \\
500\end{array}$} & \multirow{2}{*}{\multicolumn{2}{|c|}{$\begin{array}{l}\text { Split } \\
\text { nuts }\end{array}$}} & \multirow{3}{*}{ 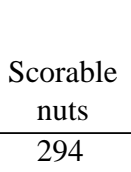 } & \multicolumn{6}{|c|}{ Location of shell split } & \multirow{3}{*}{$\frac{\chi^{2}}{<0.005}$} \\
\hline & & & & & & & \multicolumn{2}{|c|}{$\begin{array}{l}\text { Suture } \\
\text { line }\end{array}$} & \multicolumn{2}{|c|}{$\begin{array}{c}\text { Developing } \\
\text { ovule }\end{array}$} & \multicolumn{2}{|c|}{$\begin{array}{l}\text { Abortive } \\
\left(2^{\circ}\right) \text { ovule }\end{array}$} & \\
\hline & & & & 361 & $(72.2)$ & & 1 & $(0.3)$ & 63 & $(21.4)$ & 230 & $(78.2)$ & \\
\hline 2000 & Manteca & Hand & 240 & 67 & $(27.9)$ & 63 & 0 & $(0)$ & 7 & $(11.1)$ & 56 & $(88.9)$ & $<0.005$ \\
\hline 2000 & Manteca & Mechanical & 240 & 123 & $(51.3)$ & 111 & 2 & (1.8) & 16 & (14.4) & 93 & $(83.8)$ & $<0.005$ \\
\hline 2000 & Winters & Hand & 300 & 90 & $(30.0)$ & 87 & 0 & $(0)$ & 20 & $(23.0)$ & 67 & $(77.0)$ & $<0.005$ \\
\hline 2000 & Winters & Mechanical & 200 & 102 & $(51.0)$ & 76 & 1 & (1.3) & 19 & $(25.0)$ & 56 & $(73.7)$ & $<0.005$ \\
\hline
\end{tabular}




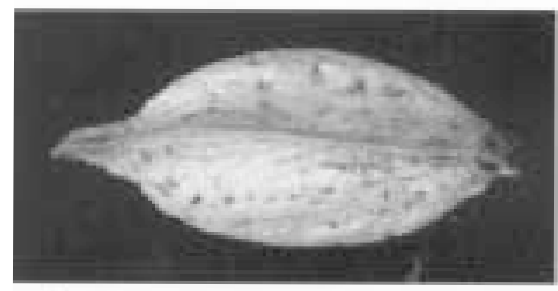

A

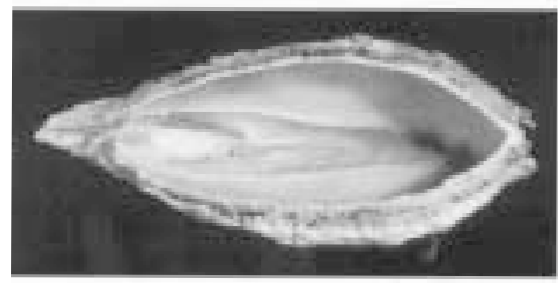

A

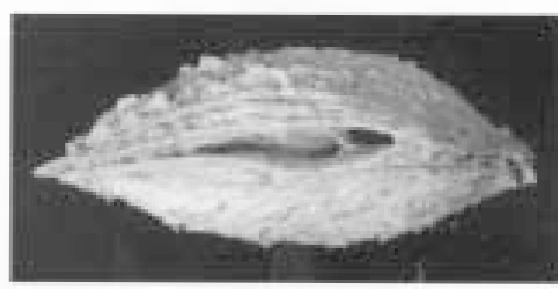

B

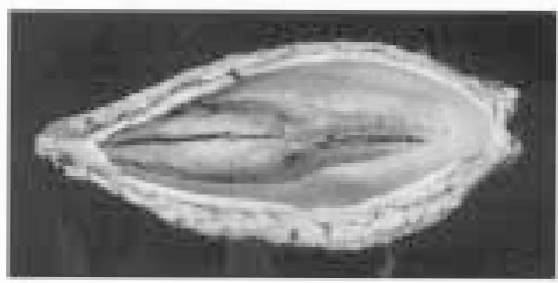

B

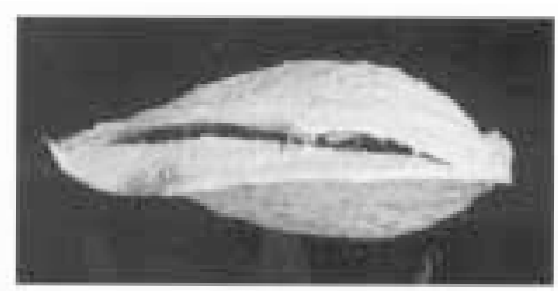

C

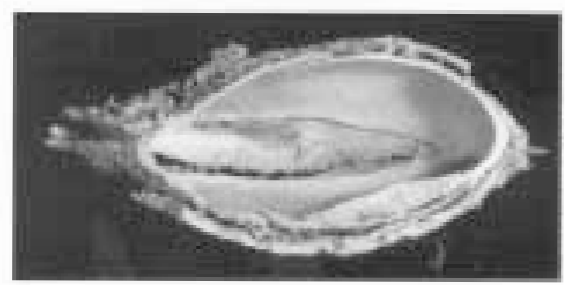

C

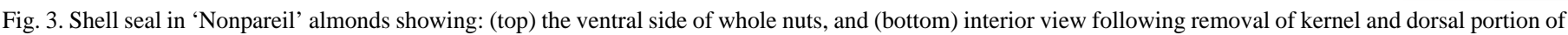
shell exposing funiculi sites at distal, stylar end of fruit $(\mathrm{A}=$ sealed shell, $\mathrm{B}=$ split at suture line, and $\mathrm{C}=$ split adjacent to suture line along the thickly lignified suture wing and through the funiculus and ventral vascular bundles).

wound site. Feeding damage before the kernel had reached full size often resulted in abortion of the ovary and consequent nut drop by $100 \mathrm{DAF}$.

\section{Discussion}

Shell splitting in almond is highly localized in its occurrence near the endocarp ventral suture. The presence of external shell splitting adjacent to, rather than at the suture line in almond could result from initial failure of the suture seal at the more highly lignified inner endocarp (as predicted by the peach split-pit model) with external splitting occurring obliquely through the funiculus and ventral vascular bundles following the path of least structural resistance, (given the soft-shelled nature of almond and the relatively massive winged structures at the suture). However, virtually all shell splits in the 'Nonpareil' nuts examined origi- nated near the funiculi, rather than the endocarp suture line, indicating a distinct mechanism for soft-shelled almonds. The close proximity of funicular and ventral vascular bundles in 'Nonpareil' (Fig. 4) makes this section particularly vulnerable to fracturing in response to physical strains during fruit development. The preponderance of splitting at the site of the secondary funiculus and associated vascular bundle (Table 1 and Fig. 3), as well as the reduced strength of the inner endocarp at this site as early as 50 DAF (Table 2 and Fig. 1), indicate that developmental as well as structural forces are involved. Since abortion of one of the two ovules in 'Nonpareil' almond occurs soon after anthesis and may be initiated before flower fertilization (unpublished data), the site of final shell splitting appears to be largely determined very early in fruit development. Interestingly, an early but obscure study of split pits in peach by Miki (1932) observed that callus formation at the site of the aborted secondary ovule and

Table 2. Endocarp strength as measured by force $(\mathrm{kg})$ required to puncture inner endocarp wall at different positions on immature almond fruit 50 $\mathrm{d}$ after flowering (SDs are in parentheses).

\begin{tabular}{|c|c|c|}
\hline \multicolumn{3}{|c|}{ Endocarp puncture force $(\mathrm{kg})$} \\
\hline $\begin{array}{l}\text { Position on inner } \\
\text { endocarp circumference } \\
\text { (degrees) }\end{array}$ & $\begin{array}{c}\text { Longitudinal section at and } \\
\text { opposite } 2^{\circ} \text { funicular bundle } \\
\text { (peduncle }=0 \text { degrees) }\end{array}$ & $\begin{array}{l}\text { Cross-section at plane } \\
\text { of funiculi attachment } \\
\text { (suture }=0 \text { degrees) }\end{array}$ \\
\hline 0 & $\mathrm{NT}^{\mathrm{z}}$ & $2.90(0.54)$ \\
\hline 10 & $2.40(0.23)$ & $0.95(0.09)$ \\
\hline 45 & $2.40(0.32)$ & $2.54(0.18)$ \\
\hline 90 & $1.69(0.27)$ & $2.49(0.18)$ \\
\hline 135 & $1.13(0.18)$ & $2.59(0.14)$ \\
\hline 170 & $1.04(0.09)$ & NT \\
\hline 180 & NT & $2.40(0.23)$ \\
\hline 190 & $2.04(0.14)$ & NT \\
\hline 225 & $2.13(0.18)$ & $2.40(0.14)$ \\
\hline 270 & $2.09(0.23)$ & $2.55(0.27)$ \\
\hline 315 & $2.00(0.18)$ & $2.63(0.23)$ \\
\hline 350 & $1.86(0.23)$ & $1.18(0.18)$ \\
\hline $\mathrm{LSD}_{0.05}$ & 0.10 & 0.12 \\
\hline
\end{tabular}

${ }^{\mathrm{z}} \mathrm{NT}=$ not tested. 
Table 3. ANOVA for force required to puncture inner endocarp wall at different positions on the fruit circumference along a) the tangential longitudinal plane at and opposite $2^{\circ}$ funicular bundle, and b) along the cross-sectional plane of funiculi attachment.

\begin{tabular}{|c|c|c|c|c|c|}
\hline Source & $\mathrm{df}$ & SS & MS & F value & $P$ value \\
\hline \multicolumn{6}{|l|}{ Longitudinal } \\
\hline Longitudinal position & 9 & 314.33 & 34.93 & 173.47 & $<0.0001$ \\
\hline Tree & 3 & 1.61 & 0.54 & 2.67 & 0.06 \\
\hline Position $\times$ tree & 27 & 3.72 & 0.14 & 0.68 & 0.88 \\
\hline Residual & 280 & 56.37 & 0.2 & & \\
\hline \multicolumn{6}{|l|}{ Cross-sectional } \\
\hline Cross-sectional position & 9 & 570.66 & 63.41 & 225.8 & $<0.0001$ \\
\hline Tree & 3 & 0.62 & 0.21 & 0.73 & 0.53 \\
\hline Position $\times$ tree & 27 & 13.63 & 0.51 & 1.8 & 0.01 \\
\hline Residual & 280 & 78.68 & 0.28 & & \\
\hline
\end{tabular}

funiculus predisposed that endocarp tissue to later splitting. The friable nature and reduced lignification observed in our examination of this tissue support such an inherent weakness, presumably resulting from its altered tissue development. If confirmed in other almond cultivars, the recognition of such an ontogenetic Achilles heel could prove useful for the genetic and cultural manipulation of shell seal quality. For example, genotypes with shell structures similar to 'Nonpareil' that have lower rates of shell splitting (IPM Manual Group, 1985; Soderstrom, 1977; Weiss, 1988) are known. Identification of the mechanism for this low shell-split trait (for example, timing of secondary ovule

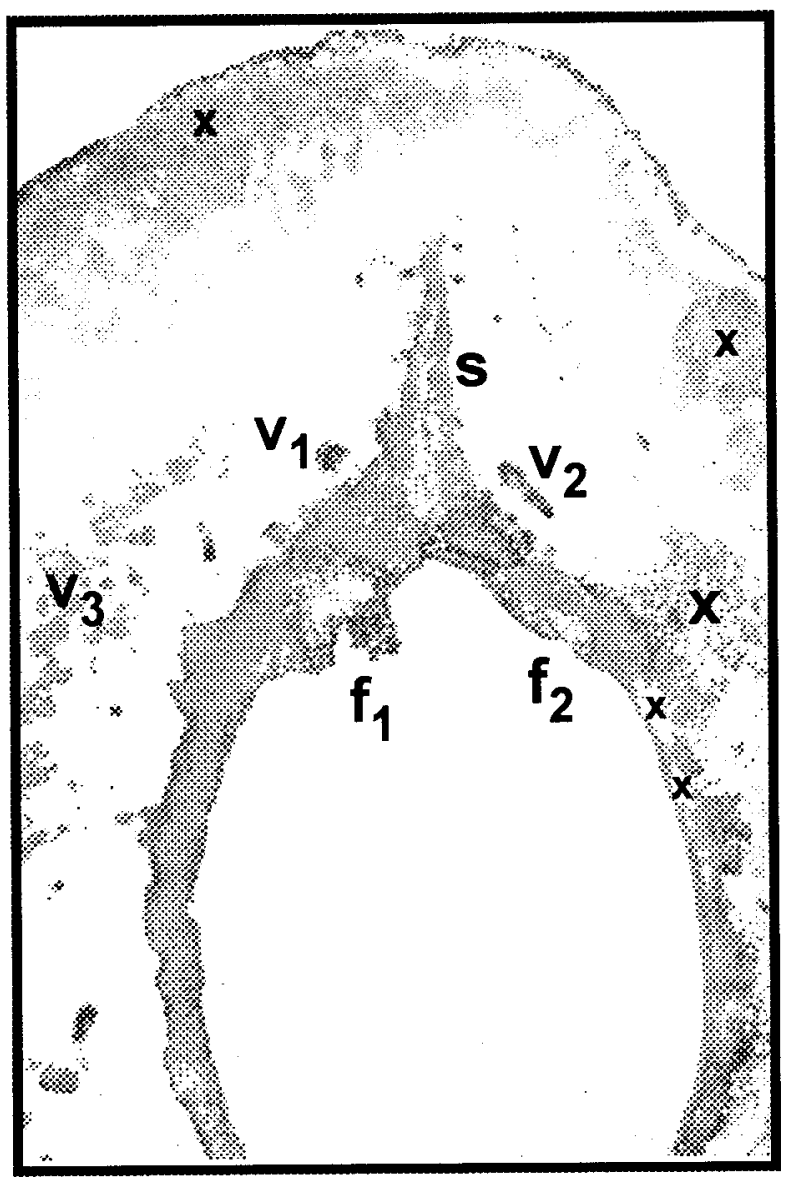

Fig. 4. Lignin distribution at ventral suture for a cross-sectional plane through funiculi of 'Nonpareil' almond fruit $130 \mathrm{DAF}\left(\mathrm{f}_{1}, \mathrm{f}_{2}=\right.$ primary, secondary funiculus; $\mathrm{V}_{1}, \mathrm{~V}_{2}=$ ventral vascular bundles; $\mathrm{V}_{3}=$ mesocarp vascular bundles; $\mathrm{s}=$ suture; $\mathrm{X}, \mathrm{x}=$ background staining from sectioning damage; image courtesy of C. Walters). abortion or increased separation between funicular and ventral vascular bundles), could lead to greater selection efficiencies for this trait. It is a desirable cultivar trait to have one of the two ovules abort early since development of both ovules results in twin, and often deformed kernels. Susceptibility to kernel meat damage by the leaffooted bug also varies with genotype and appears to result from different endocarp development and lignification rates. In 'Nonpareil', all damage to the immature but fully formed kernel occurred along the ventral suture. Insect damage to fully formed kernels is a more serious problem to processors as the consequent nut deformities predispose the kernels to disease and have to be sorted out. Most damage occurred close to the secondary funiculus, which has been shown to be the weakest tissue in the developing endocarp. Leaffooted bug preference for this region could also result from changes in vascular development associated with the ovule abortion as described by Miki (1932) in peach. Changes in vascular tissue development in the endocarp could similarly result in regional differences in endocarp desiccation and so integrity at hull split.

Opportunities for cultural manipulation are demonstrated by the $40 \%$ reduction in shell splits for nuts that were harvested by hand rather than mechanically. This finding suggests that while the developing endocarp may have internal structural weaknesses, external (i.e., mechanical shaker) forces may ultimately cause more damage than internal forces. Unlike peach, the almond mesocarp or hull is only loosely attached to the endocarp and so exerts less force on the shell during hull desiccation (hull split). Similarly, while peach split pits can often be identified in immature fruit, no instance of endocarp splitting was observed in almond until fruit desiccation and the associated hull split. The most serious damage to the almond crop occurs between the time of hull split and harvest (Crane and Summers, 1971; Curtis and Barnes, 1976; Gradziel et al., 2000; IPM Manual Group, 1985). Since the insect pests involved, navel orangeworm and to a lesser extent ants, gain access to the nut meat only through preexisting fractures in the shell (Freeman et al., 1998), any reduction in the extent and duration of postshaker kernel damage could reduce crop loss. Promising cultural practices to reduce insect feeding include the reduction of the time (typically 5 to $15 \mathrm{~d}$ ) between mechanical shaking and harvest of the nuts from the orchard floor. Alternatively, mechanical shaking directly to catch frames as with prunes (Prunus $\times$ domestica L.) and other stone fruits, could considerably reduce nut vulnerability to posthull split insect damage.

The clear association of the site of the secondary ovule/ funiculus with shell splitting in 'Nonpareil' almond has important pest management implications since 'Nonpareil' accounts for 
Table 4. Endocarp position where probing and feeding by leaffooted bugs was detected by damage to enclosed kernel and seed coat tissue.

\begin{tabular}{|c|c|c|}
\hline \multicolumn{3}{|c|}{ Leaffooted bug feeding damage } \\
\hline $\begin{array}{l}\text { Position on inner } \\
\text { endocarp circumference } \\
\text { (degrees) }\end{array}$ & $\begin{array}{l}\text { Longitudinal section at and } \\
\text { opposite } 2^{\circ} \text { funicular bundle } \\
\text { (peduncle }=0 \text { degrees) }\end{array}$ & $\begin{array}{c}\text { Cross-section at plane } \\
\text { of funiculi attachment } \\
\text { (suture = } 0 \text { degrees) }\end{array}$ \\
\hline 0 & 1 & 1 \\
\hline 10 & 0 & 16 \\
\hline 45 & 1 & 0 \\
\hline 90 & 3 & 0 \\
\hline 115 & 0 & 0 \\
\hline 135 & 5 & 0 \\
\hline 145 & 2 & 0 \\
\hline 160 & 9 & 0 \\
\hline 180 & 0 & 0 \\
\hline 225 & 0 & 0 \\
\hline 270 & 0 & 0 \\
\hline 315 & 0 & 0 \\
\hline 350 & & 4 \\
\hline
\end{tabular}

almost $50 \%$ of current U.S. production. This model is presently being tested for other California and Spanish cultivars to determine its consistency among genotypes and to better understand the crucial development processes.

\section{Literature Cited}

Almond Board of California. 2000. Almond almanac 2000. Almond Board of Calif., Modesto.

Crane, P.S. and F.M. Summers. 1971. Relationship of navel orangeworm moths to hard shell and soft shell almonds. Calif. Agr. 25:8-9.

Curtis, R.K. and M.M. Barnes. 1976. Oviposition and development of the navel orangeworm in relation of almond maturation. J. Economic Entomol. 70:395-398.

Freeman, M., C. Walters, M.A. Thorpe, and T. Gradziel. 1998. Endocarp structural components of insect resistance in almond. HortScience 33:526 (abstr.).

Fuller, G., W.W. Spooner, A.D. King, Jr., J. Schade, and B. Mackey. 1977. Survey of aflatoxins in California tree nuts. J. Amer. Oil Chem. Soc. 54:231-234.

Gradziel, T.M., N. Mahoney, and A. Abdallah. 2000. Aflatoxin production among almond genotypes is not related to either kernel oil composition or Aspergillus flavus growth rate. HortScience 34:937939.

Hawker, J.S. and M.S. Buttrose. 1980. Development of the almond nut (Prunus dulcis (Mill.) D.A. Webb): Anatomy and chemical composition of fruit parts from anthesis to maturity. Ann. Bot. 46:313-321.

IPM Manual Group, Univ. of Calif.-Davis. 1985. Integrated pest man- agement for almonds. Univ. of Calif., Div. of Agr. and Nat. Resources, Berkeley, Publ. 3308.

Kester, D.E., T.M. Gradziel, and C. Grasselly. 1991. Almonds (Prunus), p. 701-758. In: J.N. Moore and J.R. Ballington, Jr. (eds.). Genetic resources of temperate fruit and nut crops. Intl. Soc. Hort. Sci., Leuven, Belgium.

Miki, T. 1932. Studies on the development of peach fruits with special reference to the cause of their split-pit. Bul. Chiba College of Hort. 1:1118.

Phillips, D.J., M. Uota, D. Monticelli, and C. Curtis. 1976. Colonization of almond by Aspergillus flavus. J. Amer. Soc. Hort. Sci. 100:19-23.

Reid, M.R. 1992. Maturation and maturity indices, p. 25. In: A.A. Kader (ed.). Postharvest technology of horticultural crops. Univ of Calif., Div. of Agr. and Nat. Resources, Berkeley, Publ. 3311.

Ryugo, K. 1962. The accumulation of lignin and the concurrent changes in the apparent density of the cell wall in the peach endocarp. Proc. Amer. Soc. Hort. Sci. 80:197-203.

SAS Institute, Inc., 1998. StatView reference. SAS Inst., Inc., Cary, N.C. Schade, J.E., R. McGreevey, A.D. King, Jr., B. Mackey, and G. Fuller. 1975. Incidence of aflatoxin in California almonds. Appl. Microbiol. 29:48-53.

Schatzki, T.F. 1996. Distribution of aflatoxin in almonds. J. Agr. Food Chem. 44:3595-3597.

Soderstrom, E.L. 1977. Seal of almond shells and resistance to navel orangeworm. J. Econ. Entomol. 70:467-468.

Weiss, K.G. 1988. Physiology, anatomy and cytochemistry of almond [Prunus dulcis (Mill.) D.A. Webb] fruit dehiscence and abscission. PhD diss., Univ. of Calif., Davis. 